\title{
Króm(III)-pikolinát vizsgálata a talaj-növény rendszerben
}

\author{
${ }^{1}$ SZEGVÁRI ILDIKÓ, ${ }^{2}$ SIMON LÁSZLÓ és ${ }^{3}$ PROKISCH JÓZSEF \\ ${ }^{1}$ Hajdú-Bihar megyei Növény- és Talajvédelmi Szolgálat, Debrecen, \\ ${ }^{2}$ Nyíregyházi Főiskola Táj- és Környezetgazdálkodási Tanszék, Nyíregyháza és \\ ${ }^{3}$ Debreceni Egyetem Agrártudományi Centrum Regionális Agrármüszerközpont,
} Debrecen

\begin{abstract}
A talajokban lévő króm termodinamikailag stabilis formája a $\mathrm{Cr}^{3+}$, amely a talajokra jellemző kémhatás- és redoxi-viszonyok között rosszul oldódó vegyületek formájában van jelen. Az adszorpció és a csapadékképződés következtében a króm immobilissá válik, ezért a talajoldatban mért koncentrációja rendkívül kicsi: $10 \mu \mathrm{g} \cdot \mathrm{l}^{-1}$ (KABATA-PENDIAS \& PENDIAS, 2001). A talajhoz adott szerves vegyületek (pl. citromsav, DTPA, fulvósav) hatására vízoldható $\mathrm{Cr}$ (III)-komplexek keletkeznek, amelyek a $\mathrm{Cr}^{3+}$-iont a kritikus $\mathrm{pH}$-érték felett is képesek oldatban tartani (JAMES \& BARTLETT, 1983).
\end{abstract}

A talajoldat kis krómtartalma miatt a növények a talajból általában kevés krómot tudnak felvenni, a termesztett növények krómtartalma alacsony, $0,01-0,1 \mathrm{mg} \cdot \mathrm{kg}^{-1}$ értékek között változik. A zöld növények krómban gazdagabbak, mint a szemtermések vagy a gyümölcsök. A takarmányok krómtartalma az átlagosnál nagyobb, általában 0,2-0,5 mg· $\mathrm{kg}^{-1} \mathrm{közötti} \mathrm{érték} \mathrm{(SZABÓ} \mathrm{et} \mathrm{al.,} \mathrm{1993).} \mathrm{A} \mathrm{Magyarországon}$ termesztett őszi búza fajták szemterméseiben mért krómtartalom $0,11-0,12 \mathrm{mg} \cdot \mathrm{kg}^{-1}$ értékek között található (GYÖRI \& PROKISCH, 1999). A növényfajok jelentősen különböznek krómfelvételi kapacitásukban (GRUBINGER et al., 1994; SOANE \& SAUNDER, 1959). A különböző zöldségek közül nagy krómtartalmat a karalábéban $\left(18,6 \mathrm{mg} \cdot \mathrm{kg}^{-1}\right)$ és a brokkoliban $\left(14,6 \mathrm{mg} \cdot \mathrm{kg}^{-1}\right)$ mértek, az adatok szórása szintén a Brassicaceae (káposztafélék) növényeknél adódott a legnagyobbnak. Kis krómtartalom és szórás jellemezte a Solanaceae (burgonyafélék) és Fabaceae (hüvelyesek) növényfajokat; a paradicsomban $1,68 \mathrm{mg} \cdot \mathrm{kg}^{-1}$, a zöldbabban $1,04 \mathrm{mg} \cdot \mathrm{kg}^{-1} \mathrm{kon}$ centráció fordult elő (KAMBUROVA \& RANKOV, 1995). A Cr(III)-kationok felvétele energiabefektetés nélkül, apoplazmás úton, diffúzió és ioncsere révén valósul meg (SKEFFINGTON et al., 1976; SHEWRY \& PETERSON, 1974). Ebből következik, hogy a növény folyamatosan képes lenne felhalmozni a $\mathrm{Cr}$ (III)-ionokat, amennyiben az a talajoldatban rendelkezésre áll.

A Cr(III)-ionok transzlokációja a növényben kis mértékü, mivel a sejtfalhoz elektrosztatikusan kötve $\mathrm{Cr}(\mathrm{OH})_{3}$ csapadék vagy egyéb rosszul oldódó vegyületek formájában vannak jelen. A gyökérben akár tízszer-százszor nagyobb krómkon-

Postai cím: SZEGVÁRI ILDIKÓ, Hajdú-Bihar megyei Növény- és Talajvédelmi Szolgálat, 4032 Debrecen, Böszörményi út 146.E-mail: szegvarii@ontsz.hu 
centráció mérhetö, mint a föld feletti (hajtás, levél, szem) részekben (CARY et al., 1977; SRIVASTAVA et al., 1999).

A Cr(III) esszenciális mikroelem, az emberi és állati szervezetek glükóz-anyagcseréjében játszik szerepet, a glükóztolerancia-faktor alkotóelemeként az inzulinnal együtt a vércukorszintet szabályozza (MERTZ, 1975). Ezen kívül a zsírok lebontásában, a fehérjék anyagcseréjében, a nukleinsavak szintézisében vesz részt, erösíti az immunrendszert, növeli az élettartamot (MERTZ, 1982, 1993). Az emberi és állati táplálkozásban feltehetően krómhiány jelenik meg, mivel a termesztett élelmiszerés takarmánynövények krómtartalma kicsi, a növények krómtartalmát a talaj szervetlen $\mathrm{Cr}(\mathrm{III})$-vegyületekkel (pl. $\left.\mathrm{Cr}\left(\mathrm{NO}_{3}\right)_{3}\right)$ való adagolásával nem sikerült megnövelni.

A Cr(III)-pikolinát, a $\mathrm{Cr}(\mathrm{III})$-ion biológiailag felvehető komplexe, amely a humán és állati étrendben táplálék- és takarmány-kiegészítőként ismert, de a növényekre gyakorolt hatását eddig még nem tanulmányozták. A Cr(III)-pikolinát hatását a talaj-növény rendszerre tenyészedényes kísérletekben vizsgáltuk, célkitűzéseink az alábbiak voltak:

- a talaj tulajdonságainak (kémhatás, összes krómtartalom) változása,

- a növények krómfelvételének és transzlokációjának vizsgálata,

- a vegyület toxicitásának tanulmányozása a kísérlet során.

\section{Anyag és módszer}

A tenyészedényes kísérletekhez használt $\mathrm{Cr}$ (III)-pikolinát előállításához a $\mathrm{CrCl}_{3} \cdot 6 \mathrm{H}_{2} \mathrm{O}$ adott tömegéhez a pikolinsavat 1:3 sztöchiometriai aránynak megfelelö mennyiségben juttattuk ki STEARNS és ARMSTRONG (1992) szerint. Az oldódás és a komplexképződés elősegítéséhez az oldatot melegítettük, majd a reakció teljes lejátszódásához 2 percig forraltuk. A folyamatot intenzív színváltozás kísérte, mivel kezdetben az oldat a Cr(III)-klorid sötétzöld színét viselte, később azonban rózsaszínüvé alakult. A Cr(III)-pikolinát oldatból sikerült egykristályt növeszteni, így röntgendiffrakcióval meghatároztuk szerkezetét, amely megegyezik a STEARNS és ARMSTRONG (1992) cikkében közölttel.

A tenyészedényes kísérletekhez használt talaj a Debreceni Egyetem pallagi kísérleti telepéről (Debrecen-Pallag), a felső $(0-20 \mathrm{~cm})$ rétegböl származott. A humuszos homoktalaj típusba tartozó talaj tulajdonságai a Hajdú-Bihar megyei Növényés Talajvédelmi Szolgálat Talajvédelmi Laboratóriumában szabványos módszerekkel kerültek meghatározásra: $\mathrm{pH}$ (KCl): 7,48 (MSz-08-0206-2:1978); leiszapolható rész: $13,2 \mathrm{~m} / \mathrm{m} \%$ (MSz-08-0205:1978); humusz: 0,97 m/m\% (MSz-08-210:1977); szénsavas mész: $2,2 \mathrm{~m} / \mathrm{m} \%$ (MSz-08-0206-2:1978); T-érték: $6,2 \mathrm{cmol}_{\mathrm{c}} \cdot \mathrm{kg}^{-1}$ (MSz08-0215:1978); cc. $\mathrm{HNO}_{3}+$ cc. $\mathrm{H}_{2} \mathrm{O}_{2}$ oldható, ún. „összes” króm 10,6 mg $\mathrm{kg}^{-1}$ (MSz 21470-50:1998).

A kísérletek során a talajba $\mathrm{Cr}(\mathrm{III})$-pikolinát formában kijuttatott króm hatását tanulmányoztuk a króm akkumulációjára és transzlokációjára takarmányretek (Raphanus sativus L. convar. oleiformis Pers., cv. Leveles olajretek) jelzönövényben. Az első kísérletben a frissen készített $\mathrm{Cr}(\mathrm{III})$-pikolinát komplexet 0,1-1-10- 
$100 \mathrm{mg} \cdot \mathrm{kg}^{-1}$ koncentráció-sorozatban a növények vetése előtt kevertük a talajba, a légszáraz talaj nedvesítéséhez használt vízmennyiséghez adva. A második kísérletben a $\mathrm{Cr}(\mathrm{III})$-pikolinátot a növény kifejlett állapotában $10 \mathrm{mg} \cdot \mathrm{kg}^{-1}$ koncentrációban, többször (összesen négyszer) adtuk a talajhoz. A Cr(III)-pikolinát kijuttatását a talajba ez esetben öthetes növénynevelést követően kezdtük meg, az öntözővízhez hetente egyszer, összesen 4 alkalommal hozzáadva. Az első kísérletben $4 \mathrm{Cr}(\mathrm{III})$ pikolinát- + 1 kontroll-, a második kísérletben $1 \mathrm{Cr}$ (III)-pikolinát- +1 kontrollkezelést állítottunk be három ismétlésben, összesen 21 edényt használva a kísérletekhez.

A termesztő közegként használt légszáraz humuszos homoktalajt a szabadföldi vízkapacitás $75 \%$-ának megfelelő vízmennyiséggel $(270 \mathrm{ml})$ nedvesítettük vissza, majd homogenizáltuk. A talajok előkezelését követő napon a tesztnövények magvait $1500 \mathrm{~g}$ talajt tartalmazó, $16 \mathrm{~cm}$ átmérőjü mủanyag edényekbe vetettük el. Az első tenyészedényes kísérletet 1999. szeptember-november között, a második kísérletet 2000. április-június között állítottuk be a Nyíregyházi Főiskola Műszaki és Mezögazdasági Főiskolai Karának fényszobájában. Vetés után két héttel kiritkítottuk az állományt, három jól fejlett és jó térállású csíranövényt hagyva minden cserépben. A kísérletek során az edényeket véletlenszerüen helyeztük el. A fényszobában a kísérletek időtartama alatt a megvilágítást (átlagosan 12 klux 10 órán keresztül naponta), a hőmérsékletet $\left(23 \pm 3{ }^{\circ} \mathrm{C}\right)$, és a páratartalmat $(\varphi=40-50 \%)$ szabályoztuk. A növényeket 3-4 naponta ionmentesített vízzel a konstans tömeg eléréséig (a talaj szabadföldi vízkapacitásának eléréséig) öntöztük.

Az első kísérletben a talajokhoz tápanyagokat nem adtunk a kísérlet során, a második kísérletben hetente $40 \mathrm{mg} \cdot \mathrm{kg}^{-1}$ nitrogént juttattunk ki a talajra $\mathrm{NH}_{4} \mathrm{NO}_{3}$ formájában. A kísérleteket nyolc héttel a magok elvetése után bontottuk.

A kísérletek végén a növényeket kivettük a tenyészedényekből, a gyökér- és a hajtásrészek elválasztása után először csapvízzel gondosan lemostuk a talajt a gyökerekről és a hajtásokról, majd a mintákat desztillált vízzel háromszor leöblítettük. A tenyészedényenként vett növényminták $(21 \mathrm{db})$ szárazanyag-tartalmát $\left(70{ }^{\circ} \mathrm{C}\right.$, 14 óra) meghatároztuk, „összes” elemtartalmát a cc. $\mathrm{HNO}_{3}+$ cc. $\mathrm{H}_{2} \mathrm{O}_{2}$ eleggyel történő roncsolt mintákból mértük meg (MSz-08-1783-1-31:1983-1985). Talajmintákat a kísérletek elején és végén minden tenyészedényböl $0-10 \mathrm{~cm}$ mélységből, 10 leszúrásból vettünk, melyekből átlagmintát képeztünk (21 db). A talajok „összes” krómtartalmát cc. $\mathrm{HNO}_{3}+\mathrm{cc} . \mathrm{H}_{2} \mathrm{O}_{2}$ eleggyel történő roncsolás után határoztuk meg (MSz 21470-50:1998), kémhatását $\left(\mathrm{pH}\left(\mathrm{H}_{2} \mathrm{O}\right)\right.$ ) ioncserélt vízzel 1:2,5 tömeg/térfogat arányban készített szuszpenzióban mértük meg (MSz-08-0206/2:1978). A roncsolt minták elemanalízise a Debreceni Egyetem Agrártudományi Centrum Regionális Agrármüszerközpontjában történt Perkin Elmer gyártmányú Optima 3300DV típusú ICP-OES készülékkel.

A különböző koncentrációjú $\mathrm{Cr}(\mathrm{III})$-pikolinát-kezelések hatását a növények krómfelvételére és -transzlokációjára a koncentrációhányados és transzport index alapján hasonlítottuk össze, amelyeket ATHALYE és munkatársai (1995) szerint számoltuk ki. A koncentrációhányadosokat (CR-concentration ratio) a növényi szervekben (gyökér, hajtás) és a talajban mért króm mennyiségének százszorosaként, a transzport indexeket (TI-transport index) a hajtásban és az egész növényben mért krómmennyiségek hányadosának százszoros értékeként számítottuk ki, a mért 
„összes” krómkoncentrációk alapján. A kísérletek eredményeinek statisztikai elemzését SPSS 12.0.1 programmal, varianciaanalízist alkalmazva, a Tukey-féle b-teszt alapján végeztük el.

\section{Eredmények és értékelésük}

A termesztő közegként használt humuszos homoktalaj kémhatásának és „öszszes" krómtartalmának változását a tenyészidő alatt a különböző koncentrációjú Cr(III)-pikolinát-kezelések hatására az 1. táblázat foglalja össze.

\section{1. táblázat}

A Cr(III)-pikolinát (Cr-pik) alkalmazásának hatására mért pH-értékek és „összes” króm mennyiségek a talajban

\begin{tabular}{|c|c|c|c|c|}
\hline \multirow{2}{*}{$\begin{array}{c}\text { (1) } \\
\text { Kezelés } \\
\mathrm{mg} \cdot \mathrm{kg}^{-1} \\
\text { Cr-pik }\end{array}$} & \multicolumn{2}{|c|}{$\begin{array}{c}\text { (2) } \\
\text { Kísérlet előtt }\end{array}$} & \multicolumn{2}{|c|}{$\begin{array}{c}\text { (4) } \\
\text { Kísérlet után }\end{array}$} \\
\hline & $\mathrm{pH}\left(\mathrm{H}_{2} \mathrm{O}\right)$ & $\begin{array}{c}\text { (3) } \\
\text { "Összes" króm } \\
{\left[\mathrm{mg} \cdot \mathrm{kg}^{-1}\right]}\end{array}$ & $\mathrm{pH}\left(\mathrm{H}_{2} \mathrm{O}\right)$ & $\begin{array}{c}\text { (3) } \\
\text { "Összes" króm } \\
{\left[\mathrm{mg} \cdot \mathrm{kg}^{-1}\right]}\end{array}$ \\
\hline a) Kontroll & 7,96 & $12,9^{\mathrm{a}}$ & 7,80 & $9,44^{\mathrm{a}}$ \\
\hline 0,1 & 7,94 & $12,5^{\mathrm{a}}$ & 7,94 & $9,48^{\mathrm{a}}$ \\
\hline 1 & 7,97 & $13,6^{\mathrm{a}}$ & 7,88 & $9,40^{\mathrm{a}}$ \\
\hline 10 & 8,01 & $22,7^{b}$ & 7,80 & $16,3^{b}$ \\
\hline 100 & 7,63 & $99,8^{\mathrm{c}}$ & 7,77 & $80,0^{\mathrm{c}}$ \\
\hline a) Kontroll & - & $10,6^{\mathrm{a}}$ & - & $10,5^{\mathrm{a}}$ \\
\hline $4 \times 10$ & - & $10,7^{\mathrm{a}}$ & - & $39,0^{\mathrm{b}}$ \\
\hline
\end{tabular}

Megjegyzés: A különböző betüindexeket kapott értékek szignifikánsan $(\mathrm{P}<0,05)$ különböznek egymástól; $\mathrm{n}=3$

Az alkalmazott $\mathrm{Cr}$ (III)-pikolinát nem befolyásolta jelentősen a talaj kémhatását, amely a kísérlet ideje alatt a gyengén lúgos tartományban maradt. A termesztö közegként használt humuszos homoktalaj „összes” krómtartalma a tenyészidő alatt 20-30\%-kal csökkent, a növényi felvétel és a talajban történő kicsapódás következtében. A legnagyobb mértékủ változás a nagy koncentrációjú $\left(100 \mathrm{mg} \cdot \mathrm{kg}^{-1}\right)$ kezelésnél mutatkozott, amelynél $20 \mathrm{mg} \cdot \mathrm{kg}^{-1}$ értékkel csökkent a talaj krómtartalma a kísérlet során. A második kísérletben a talaj „összes” krómtartalma a kísérlet végére több mint három és félszeresére növekedett a bevitel eredményeképpen.

A növénynevelés elött, növekvő koncentrációban kijuttatott Cr(III)-pikolinát komplex hatására a takarmányretek különböző növényi szerveiben megjelenő krómkoncentrációkat az 1A. ábra mutatja be.

Az egyes növényi szervek krómtartalmának növekedése már a kis koncentrációkban alkalmazott $\mathrm{Cr}$ (III)-pikolinát esetében is megnyilvánul. Jelentősebb emelkedést a gyökérben $1 \mathrm{mg} \cdot \mathrm{kg}^{-1}$, a hajtásban $10 \mathrm{mg} \cdot \mathrm{kg}^{-1}$ dózis felett tapasztaltunk. A nagy adagú $\left(100 \mathrm{mg} \cdot \mathrm{kg}^{-1}\right) \mathrm{Cr}(\mathrm{III})$-pikolinát-kezelés hatására a kontrollhoz viszonyí- 
A
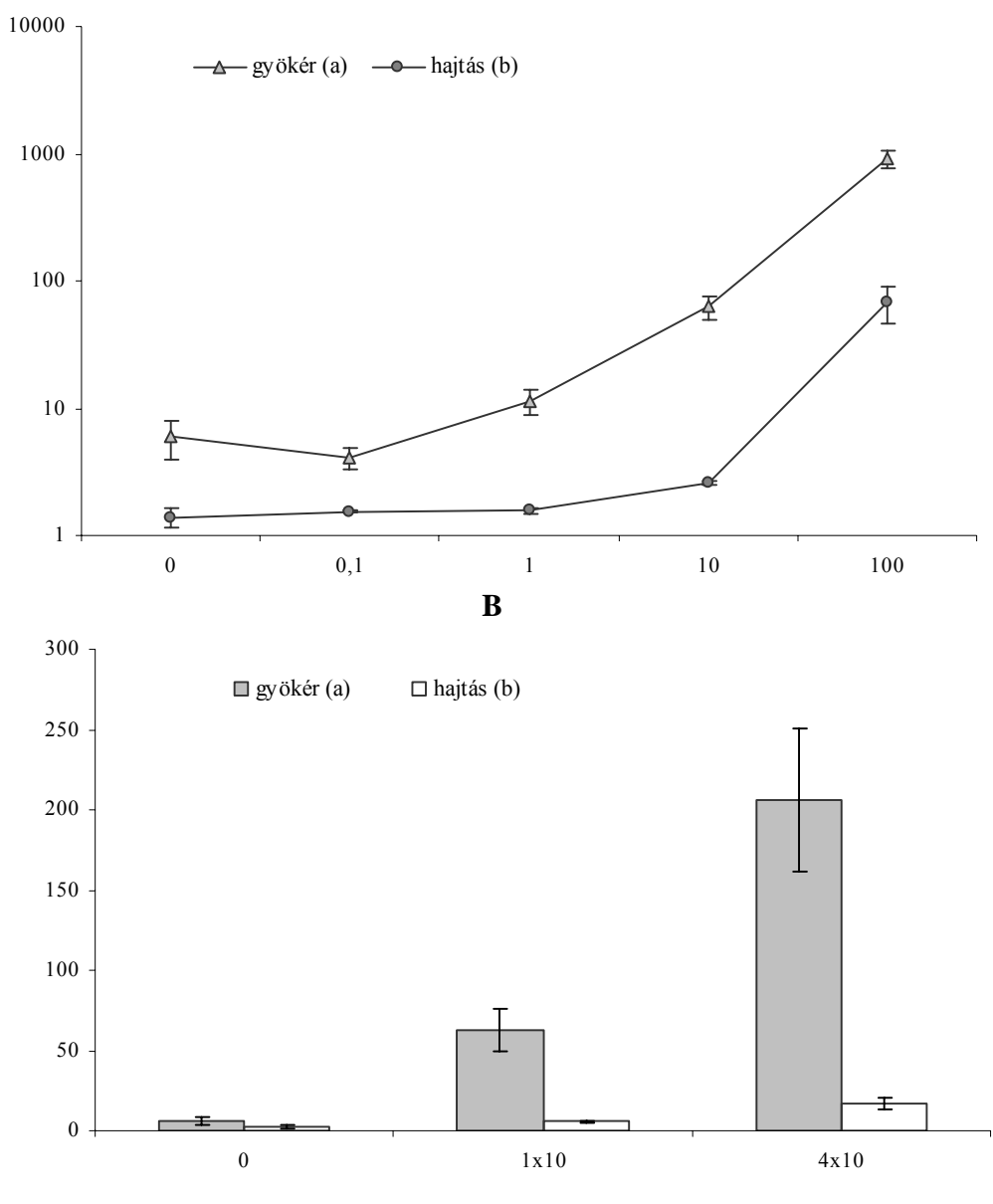

1. ábra

A különböző koncentrációkban (A), valamint az egyszer, illetve többször $10 \mathrm{mg} \cdot \mathrm{kg}^{-1}$ koncentrációban (B) kijuttatott Cr(III)-pikolinát (Cr-pik) hatása a takarmányretek krómakkumulációjára. Vízszintes tengely: Talajhoz adott $\mathrm{Cr}$-pik, $\mathrm{mg} \cdot \mathrm{kg}^{-1}$. Függőleges tengely: Összes króm a növényben, $\mathrm{mg} \cdot \mathrm{kg}^{-1}$

tott krómkoncentráció a takarmányretek gyökerében 150-szeresére, hajtásában 50szeresére nőtt.

Az első kísérlet során a talajra kis dózisban $\left(10 \mathrm{mg} \cdot \mathrm{kg}^{-1}\right)$ egyszer, illetve a második kísérletben többször $\left(4 \times 10 \mathrm{mg} \cdot \mathrm{kg}^{-1}\right)$ kijuttatott $\mathrm{Cr}(\mathrm{III})$-pikolinát esetén a krómkoncentrációkat a takarmányretek különböző szerveiben az 1B. ábrán hasonlítjuk össze.

A tesztnövény egyes növényi szerveiben mért krómkoncentrációkat a kontrollhoz viszonyítva megállapíthatjuk, hogy a talajra $10 \mathrm{mg} \cdot \mathrm{kg}^{-1}$ koncentrációban egyszer kijuttatott $\mathrm{Cr}(\mathrm{III})$-pikolinát a takarmányretek gyökerében tízszer, a hajtásában 
kétszer több krómot eredményezett. A talajra többször (hetente) öntözéssel kiadott Cr(III)-pikolinát hatására a gyökérben harmincötször, a hajtásban tizenkétszer nagyobb krómkoncentráció jelent meg a kezeletlen kultúra krómtartalmához képest.

A különböző koncentrációjú Cr(III)-pikolinát kezelések krómakkumulációra kifejtett hatását a takarmányretek gyökerében és hajtásában, a növényben és a talaj-

\section{2. táblázat}

A takarmányretek gyökerében és hajtásában mért „összes” króm, szárazanyaghozam, valamint a krómra vonatkozó koncentrációhányados (CR) és transzport index (TI) értékek a különböző koncentrációjú Cr(III)-pikolinát (Cr-pik) kezelések hatására

\begin{tabular}{|c|c|c|c|c|c|c|c|}
\hline \multirow{2}{*}{$\begin{array}{c}\text { (1) } \\
\text { Kezelés } \\
(\mathrm{Cr}-\text { pik}) \\
\mathrm{mg} \cdot \mathrm{kg}^{-1}\end{array}$} & \multicolumn{2}{|c|}{$\begin{array}{c}\text { (2) } \\
\text { "Összes" króm } \\
\mathrm{mg} \cdot \mathrm{kg}^{-1}\end{array}$} & \multicolumn{2}{|c|}{$\begin{array}{c}(5) \\
\text { Szárazanyag } \\
\text { g·növény }\end{array}$} & \multicolumn{2}{|c|}{$\mathrm{CR}$} & \multirow{2}{*}{ TI } \\
\hline & $\begin{array}{c}\text { (3) } \\
\text { Gyökér }\end{array}$ & $\begin{array}{c}\text { (4) } \\
\text { Hajtás }\end{array}$ & $\begin{array}{c}\text { (3) } \\
\text { Gyökér }\end{array}$ & $\begin{array}{c}\text { (4) } \\
\text { Hajtás }\end{array}$ & $\begin{array}{c}\text { (3) } \\
\text { Gyökér }\end{array}$ & $\begin{array}{c}\text { (4) } \\
\text { Hajtás }\end{array}$ & \\
\hline a) Kontroll & 5,98 & 1,38 & 0,16 & 1,12 & 63 & 15 & 19 \\
\hline 0,1 & 4,08 & 1,54 & 0,12 & 0,99 & 43 & 16 & 27 \\
\hline 1 & 11,3 & 1,57 & 0,12 & 0,84 & 120 & 17 & 12 \\
\hline 10 & 62,6 & 2,61 & 0,20 & 1,06 & 385 & 16 & 4,0 \\
\hline 100 & 901 & 67,6 & 0,01 & 0,08 & 1130 & 85 & 7,0 \\
\hline a) Kontroll & 2,97 & 0,38 & 0,15 & 1,19 & 28 & 4 & 11 \\
\hline $4 \times 10$ & 206 & 17,0 & 0,24 & 1,29 & 528 & 44 & 7,6 \\
\hline
\end{tabular}

Megjegyzés: $\mathrm{CR}=\mathrm{Cr}_{\text {gyökér }} / \mathrm{Cr}_{\text {talaj }} \times 100 ; \mathrm{Cr}_{\text {hajtás }} / \mathrm{Cr}_{\text {talaj }} \times 100 ; \mathrm{TI}=\mathrm{Cr}_{\text {hajtás }} / \mathrm{Cr}_{\text {hajtás }}+\mathrm{Cr}_{\text {gyökér }} \times 100$

ban mért krómkoncentráció egymáshoz viszonyított aránya alapján vizsgáltuk meg. A króm növényen belüli szállítását a transzport indexszel és a koncentrációhányadossal (CR) jellemeztük (2. táblázat).

A talajra növekvő koncentrációkban kijuttatott $\mathrm{Cr}$ (III)-pikolinát esetén a takarmányretek gyökerében már az $1 \mathrm{mg} \cdot \mathrm{kg}^{-1}$ kezelésnél többszörösére emelkedett a krómra vonatkozó koncentrációhányados, míg ez a hatás a hajtásban csak a $100 \mathrm{mg} \cdot \mathrm{kg}^{-1}$ kezelésnél nyilvánult meg. A többször kijuttatott $\mathrm{Cr}$ (III)-pikolinát a takarmányretek gyökerében és hajtásában is többszörösére növelte a koncentrációhányadost. A takarmányretek növényben a króm szállítása kismértékü, a hajtás krómtartalma néhány százalékát teszi ki a növény teljes krómtartalmának. A 10 és $100 \mathrm{mg} \cdot \mathrm{kg}^{-1}$ koncentrációkban alkalmazott $\mathrm{Cr}$ (III)-pikolinát megnövelte a króm szállítását a takarmányretek gyökeréből a hajtásába, míg az ettől kisebb koncentrációjú $\left(0,1\right.$ és $\left.1 \mathrm{mg} \cdot \mathrm{kg}^{-1}\right)$ kezeléseknél ez a hatás nem volt megfigyelhető. A $10 \mathrm{mg} \cdot \mathrm{kg}^{-1}$ koncentrációban többször kijuttatott $\mathrm{Cr}$ (III)-pikolinát nagyobb mértékben segítette elö a króm szállítását a takarmányretek növényben az azonos koncentrációjú egyszeri kijuttatáshoz képest.

Az egyes kezelések toxikus hatását a takarmányretek növény biomassza hozama alapján állapítottuk meg, amelyet a különböző koncentrációjú $\operatorname{Cr}$ (III)-pikolinátkezelések esetén a 2. ábra mutat be. 


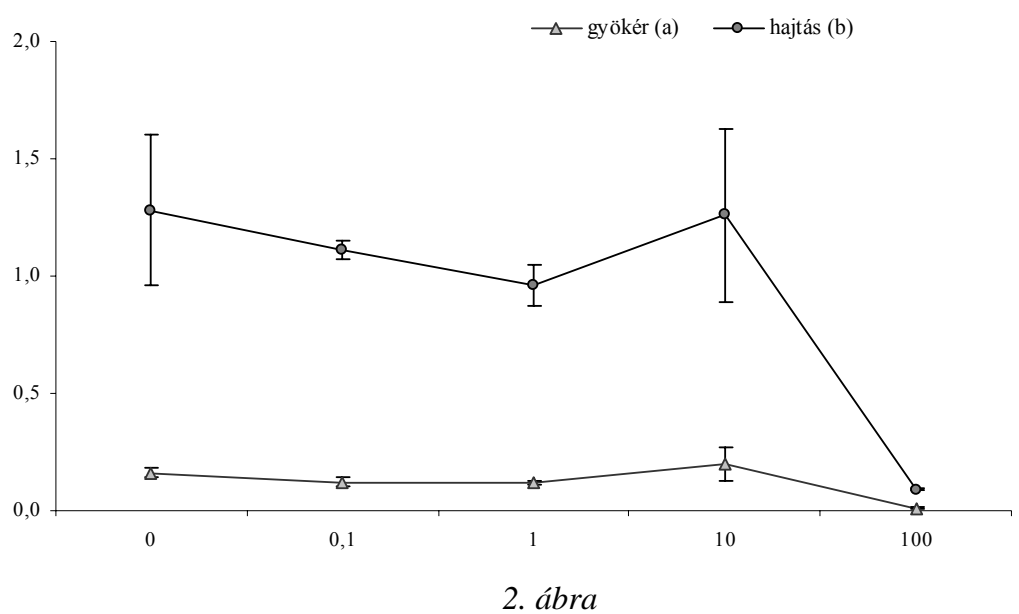

A különböző koncentrációkban kijuttatott $\mathrm{Cr}$ (III)-pikolinát (Cr-pik) hatása a takarmányretek szárazanyag hozamára. Vízszintes tengely: Talajhoz adott Cr-pik, $\mathrm{mg} \cdot \mathrm{kg}^{-1}$. Függőleges tengely: Szárazanyag, $g \cdot$ növény $^{-1}$

A talajba $0,1-100 \mathrm{mg} \cdot \mathrm{kg}^{-1}$ koncentrációtartományban kijuttatott Cr(III)-pikolinát hatására a takarmányretek növény szárazanyag produkciója $10 \mathrm{mg} \cdot \mathrm{kg}^{-1}$ dózisig nem változik jelentősen, további koncentrációnövelés esetén azonban nagymértékben lecsökken. A $10 \mathrm{mg} \cdot \mathrm{kg}^{-1}$ dózisnál nagyobb mértékü Cr(III)-pikolinát-kezelések fitotoxikus hatást gyakoroltak a tesztnövényre, amely a szárazanyag-akkumuláció viszszaesése mellett az egyes növényi szervek elváltozásában nyilvánult meg. A krómmérgezés tünetei jelentkeztek ezeken a növényeken; azaz a gyengén fejlett gyökérzet barnás színeződését, a szárak lilás színeződését, valamint kisméretű és sötétzöld levelek megjelenését figyelhettük meg.

\section{Összefoglalás}

A Cr(III)-pikolinát hatását vizsgáltuk a takarmányretek (Raphanus sativus L. convar. oleiformis Pers., cv. Leveles olajretek) krómfelvételére tenyészedényes kísérletekben. Az első kísérletben öt $\left(0-0,1-1-10-100 \mathrm{mg} \cdot \mathrm{kg}^{-1}\right.$ koncentráció), a második kísérletben két kezelést (1×, ill. $4 \times 10 \mathrm{mg} \cdot \mathrm{kg}^{-1} \mathrm{koncentráció)} \mathrm{állítottunk} \mathrm{be}$ három ismétlésben, összesen 21 edényt használva a kísérletekhez. A humuszos homoktalajban $[\mathrm{pH}(\mathrm{KCl})$ : 7,48; leiszapolható rész: $13,2 \mathrm{~m} / \mathrm{m} \%$; humusz: $0,97 \mathrm{~m} /$ m\%; szénsavas mész: 2,2 m/m\%; T-érték: $6,2 \mathrm{cmol}_{\mathrm{c}} \cdot \mathrm{kg}^{-1}$; „összes” króm: 10,6 $\left.\mathrm{mg} \cdot \mathrm{kg}^{-1}\right]$ nevelt növények kis mennyiségü krómot akkumuláltak gyökerükben $\left(5,98 \mathrm{mg} \cdot \mathrm{kg}^{-1}\right)$ és hajtásukban $\left(1,38 \mathrm{mg} \cdot \mathrm{kg}^{-1}\right)$. A talajba közvetlenül kijuttatott Cr(III)-pikolinát hatására jelentősen megnőtt a takarmányretek hajtásának, illetve gyökerének krómtartalma. A kisdózisú kezelés hatására $\left(10 \mathrm{mg} \cdot \mathrm{kg}^{-1}\right)$ a gyökérben tízszer, a hajtásban kétszer több króm jelent meg; a nagydózisú kezelés (100 
$\mathrm{mg} \cdot \mathrm{kg}^{-1}$ ) egy nagyságrenddel nagyobb mértékủ növekedést mutatott, a gyökérben százötvenszer, a hajtásban ötvenszer több krómot mértünk. A nagy dózisban $\left(100 \mathrm{mg} \cdot \mathrm{kg}^{-1}\right)$ és a többször kis koncentrációban $\left(4 \times 10 \mathrm{mg} \cdot \mathrm{kg}^{-1}\right)$ kijuttatott $\mathrm{Cr}(\mathrm{III})$ pikolinát közel azonos mértékben növelte meg a króm transzlokációját a takarmányretek növényben, mindkét kezelésnél a hajtás krómtartalma a teljes növény krómtartalmához viszonyítva azonos értékünek adódott $(\mathrm{TI}=7)$. A többször kijuttatott $\mathrm{Cr}(\mathrm{III})$-pikolinát hatására az egyes növényi szervek krómtartalma a többszörösére növekedett; a gyökérben háromszor, a hajtásban hatszor nagyobb krómkoncentráció jelent meg az azonos koncentrációjú, egyszeri kezeléshez képest.

A Cr(III)-pikolinát jelentős mértékben megnövelte a króm felvételét a talajnövény rendszerben. Ennek a jelenségnek gyakorlati jelentősége lehet a krómmal szennyezett talajok növényekkel történő tisztítása (fitoremediációja), illetve a krómmal dúsított növények előállítása során.

A kutatást az OTKA T 042534 pályázat és a Bolyai Ösztöndíjalap támogatta.

Kulcsszavak: króm, $\mathrm{Cr}(\mathrm{III})$-pikolinát, takarmányretek, transzlokáció, tenyészedényes kísérlet

\section{Irodalom}

Athalye, V. V., RamachandRan, V. \& D'Souza, T. J., 1995. Influence of chelating agents on plant uptake of $51 \mathrm{Cr}, 210 \mathrm{~Pb}$ and $210 \mathrm{Po}$. Environm. Poll. 89. 47-53.

CARY, E. E., Allaway, W. H. \& Olson, O. E., 1977. Control of chromium concentrations in food plants. I. Absorption and translocation of chromium in plants. J. Agric. Food Chem. 25. 300-304.

GrubingER, V. P. et al., 1994. Chromium in swiss chard grown on soil amended with tannery meal fertilizer. Chemosphere. 4. 717-720.

GYÖRI, Z. \& PROKISCH, J., 1999. Determination of the chromium content of Hungarian winter wheat. J. Agric. Food Chem. 47. 2751-2754.

James, B. R. \& BARTLETT, R. J., 1983. Behavior of chromium in soils. V. Fate of organically complexed $\mathrm{Cr}$ (III) added to soil. J. Environm. Qual. 12. 169-172.

Kabata-Pendias, A. \& Pendias, H., 2001. Trace Elements in Soils and Plants. $3^{\text {rd }}$ ed. CRC Press. Washington, D. C.

KAMBUROVA, M. \& RANKOV, V., 1995. The chromium content in the products of some vegetables. Agrochimica. 39. 260-266.

MERTZ, W., 1975. Effects and metabolism of glucose tolerance factor. Nutr. Rev. 33. $129-135$.

MERTZ, W., 1982. Clinical and public health significance of chromium. In: Clinical, Biochemical and Nutritional Aspects of Trace Elements. (Ed.: PrASAD, A. S.) 315-323. Alan Liss Inc. New York.

MERTZ, W., 1993. Chromium in human nutrition: a review. J. Nutr. 123. 626-633.

Shewry, P. R. \& Peterson, P. J., 1974. The uptake and translocation of chromium by barley seedlings (Hordeum vulgare L.). J. Experim. Bot. 25. 785-707. 
Skeffington, R. A., Shewry, P. R. \& Peterson, P. J., 1976. Chromium uptake and transport in barley seedlings (Hordeum vulgare L.). Planta. 132. 209-214.

SoAne, B. D. \& SAUNDER, D. H., 1959. Nickel and chromium toxicity of serpentine soils in southern Rhodesia. Soil Sci. 84. 322-329.

Srivastava, S., Prakash, S. \& Srivastava, M. M., 1999. Chromium mobilization and plant availability - the impact of organic complexing ligands. Plant and Soil. 212. 203-208.

SteARnS, D. M. \& ARMSTRONG, W. H., 1992. Monomuclear and binuclear chromium(III) picolinate complexes. Inorg. Chem. 31. 5178-5184.

SzABÓ S. A., GYÖRI D. \& REgIUSNÉ M. A., 1993. Mikroelemek a mezőgazdaságban. II. Stimulatív hatású mikroelemek. Akadémiai Kiadó. Budapest.

Érkezett: 2005. április 9. 


\title{
Investigation of $\mathbf{C r}$ (III) Picolinate in a Soil-Plant System
}

\author{
${ }^{1}$ I. SZEGVÁRI, ${ }^{2}$ L. SimON and ${ }^{3}$ J. ProKISCH \\ ${ }^{1}$ Plant and Soil Conservation Station of Hajdú-Bihar County, Debrecen, ${ }^{2}$ Technical and \\ Agricultural Faculty, College of Nyíregyháza, Nyíregyháza, ${ }^{3}$ Centre of Agricultural \\ Sciences, Debrecen University, Debrecen (Hungary)
}

\section{Summary}

The effect of $\mathrm{Cr}(\mathrm{III})$ picolinate (organically bound stable complex of $\mathrm{Cr}$ ) was studied on the chromium accumulation of fodder radish (Raphanus sativus L. convar. oleiformis Pers., cv. Leveles olajretek) grown in pot experiments. The first experiment involved five treatments $\left(0-0.1-1-10-100 \mathrm{mg} \cdot \mathrm{kg}^{-1}\right.$ concentration) and the second two $(1 \times$ and $4 \times 10 \mathrm{mg} \cdot \mathrm{kg}^{-1}$ concentration), carried out in three replications, giving a total of 21 pots. Control cultures, grown in an uncontaminated humous sandy soil $\left(\mathrm{pH}_{\mathrm{KCl}} 7.48\right.$; sand texture with $13.2 \mathrm{~m} / \mathrm{m} \%$ clay+silt content; humus $0.97 \mathrm{~m} / \mathrm{m} \% ; \mathrm{CaCO}_{3} 2.2 \mathrm{~m} / \mathrm{m} \%$; CEC $6.2 \mathrm{cmol}_{\mathrm{c}} \cdot \mathrm{kg}^{-1}$; cc. $\mathrm{HNO}_{3}+\mathrm{cc} . \mathrm{H}_{2} \mathrm{O}_{2}$-soluble, "total" $\mathrm{Cr} 10.6 \mathrm{mg} \cdot \mathrm{kg}^{-1}$ ), accumulated low amounts of chromium in their roots and shoots $\left(5.98\right.$ and $\left.1.38 \mathrm{mg} \cdot \mathrm{kg}^{-1}\right)$. When this uncontaminated soil was treated with $\mathrm{Cr}(\mathrm{III})$ picolinate before plant cultivation, the accumulation of $\mathrm{Cr}$ in the shoots and roots increased considerably. The $\mathrm{Cr}$ concentration was 10 times and twice as high in the roots and shoots on soil treated with a low dose of $\mathrm{Cr}(\mathrm{III})$-picolinate $\left(10 \mathrm{mg} \cdot \mathrm{kg}^{-1}\right)$, while after the application of a high dose of $\mathrm{Cr}(\mathrm{III})$ picolinate $\left(100 \mathrm{mg} \cdot \mathrm{kg}^{-1}\right)$ the $\mathrm{Cr}$ concentration was 150 and 50 times higher in the roots and shoots than in the control, resp. The high dose $\left(100 \mathrm{mg} \cdot \mathrm{kg}^{-1}\right)$ or the repeated application of the low dose $\left(4 \times 10 \mathrm{mg} \cdot \mathrm{kg}^{-1}\right)$ of $\mathrm{Cr}(\mathrm{III})$ picolinate enhanced the $\mathrm{Cr}$ translocation in fodder radish to approximately the same degree: the ratio of the $\mathrm{Cr}$ concentration in the shoots to that in the whole plant (transport index) had the same value in both treatments $(\mathrm{TI}=7)$. Repeated treatment of the soil with $\mathrm{Cr}(\mathrm{III})$ picolinate $\left(4 \times 10 \mathrm{mg} \cdot \mathrm{kg}^{-1}\right)$ during plant growth greatly enhanced the $\mathrm{Cr}$ concentrations in the plant organs, which were three and six times as high in the roots and shoots as compared to a single application $\left(1 \times 10 \mathrm{mg} \cdot \mathrm{kg}^{-1}\right)$. Cr(III) picolinate caused a considerable increase in the uptake and translocation of $\mathrm{Cr}$ in the soil-plant system. This could be utilized in the phytoremediation of soils contaminated with $\mathrm{Cr}$, or in the production of foodstuffs enriched with $\mathrm{Cr}$.

Table 1. Changes in the $\mathrm{pH}$ and "total" $\mathrm{Cr}$ content of the soil as the result of $\mathrm{Cr}(\mathrm{III})$ picolinate (Cr-pik) application. (1) Treatment, $\mathrm{mg} \cdot \mathrm{kg}^{-1}$. a) Control. (2) Prior to the experiment. (3) "Total" chromium, $\mathrm{mg} \cdot \mathrm{kg}^{-1}$. (4) After the experiment. Note: Data designated by different letters differed significantly from each other $(\mathrm{P}<0.05) ; \mathrm{n}=3$.

Table 2. "Total" chromium and dry matter content of the roots and shoots of fodder radish, and the concentration ratio $(\mathrm{CR})$ and transport index (TI) for chromium after treatment with various concentrations of $\mathrm{Cr}$ (III)-picolinate. (1): see Table 1. (2) "Total" chromium, $\mathrm{mg} \cdot \mathrm{kg}^{-1}$. (3) Root. (4) Shoot. (5) Dry matter, g.plant ${ }^{-1}$.

Fig. 1. Effect of $\mathrm{Cr}(\mathrm{III})$-picolinate (Cr-pik) applied in various concentrations (A) or in one or more $10 \mathrm{mg} \cdot \mathrm{kg}^{-1}$ doses (B) on the Cr-accumulation of fodder radish. Horizontal axis: Cr-pik applied to the soil, $\mathrm{mg} \cdot \mathrm{kg}^{-1}$. Vertical axis: Total $\mathrm{Cr}$ in the plant, $\mathrm{mg} \cdot \mathrm{kg}^{-1}$.

Fig. 2. Effect of $\mathrm{Cr}(\mathrm{III})$-picolinate (Cr-pik) applied in various concentrations on the dry matter yield of fodder radish. Horizontal axis: See Fig. 1. Vertical axis: Dry matter, g.plant ${ }^{-1}$. 